
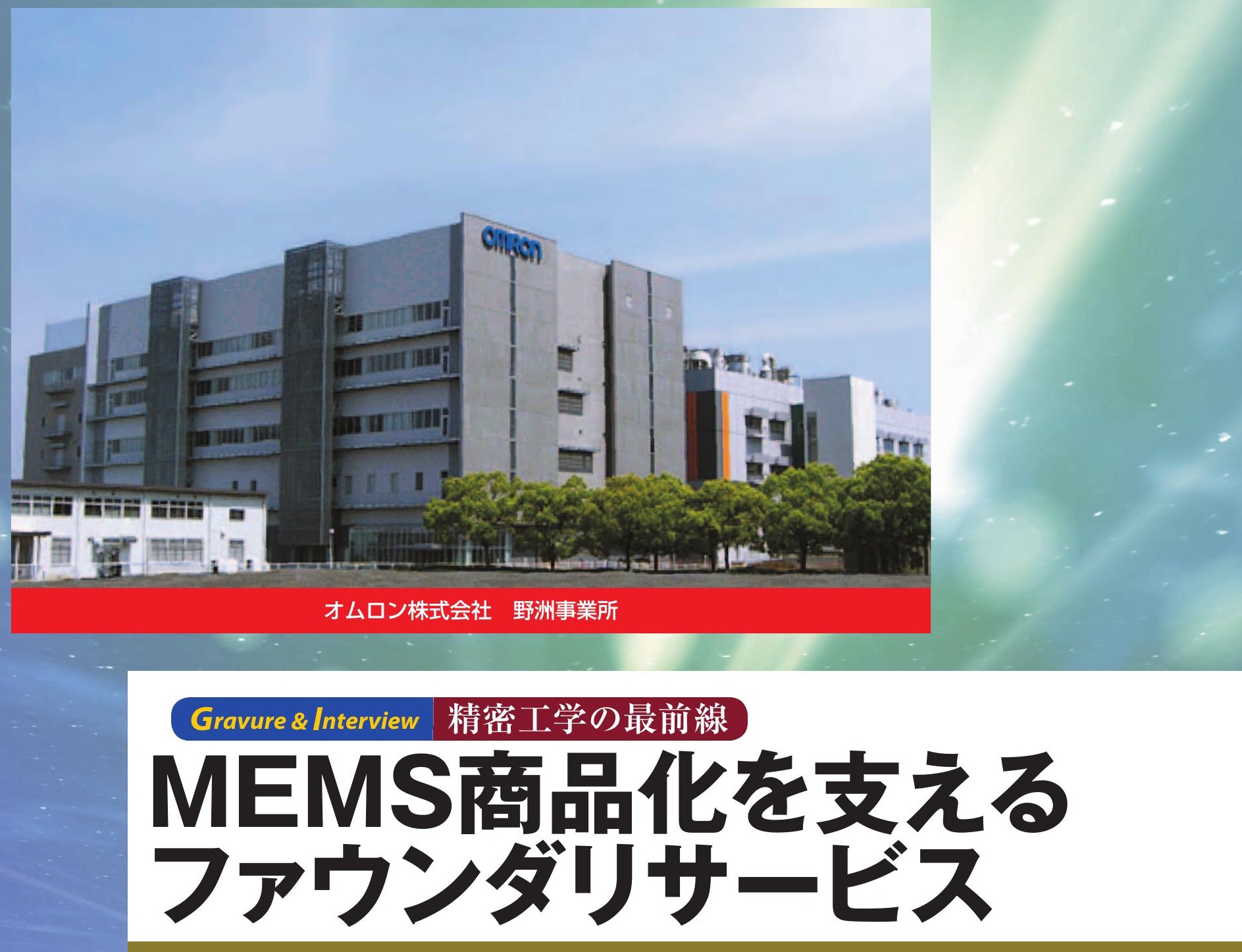

オムロン株式会社マイクロデバイス事業部

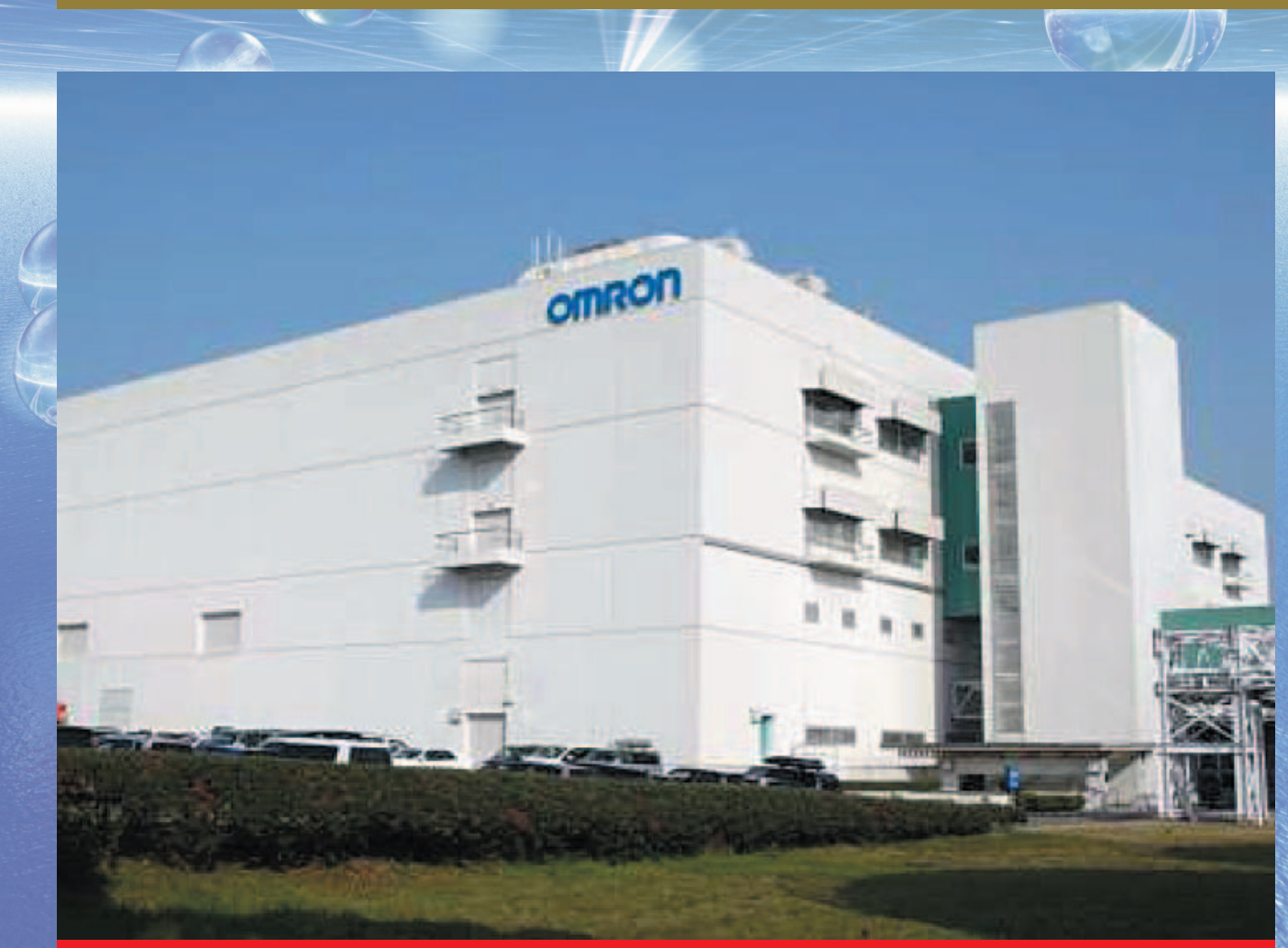

野洲事業所（生産棟） 


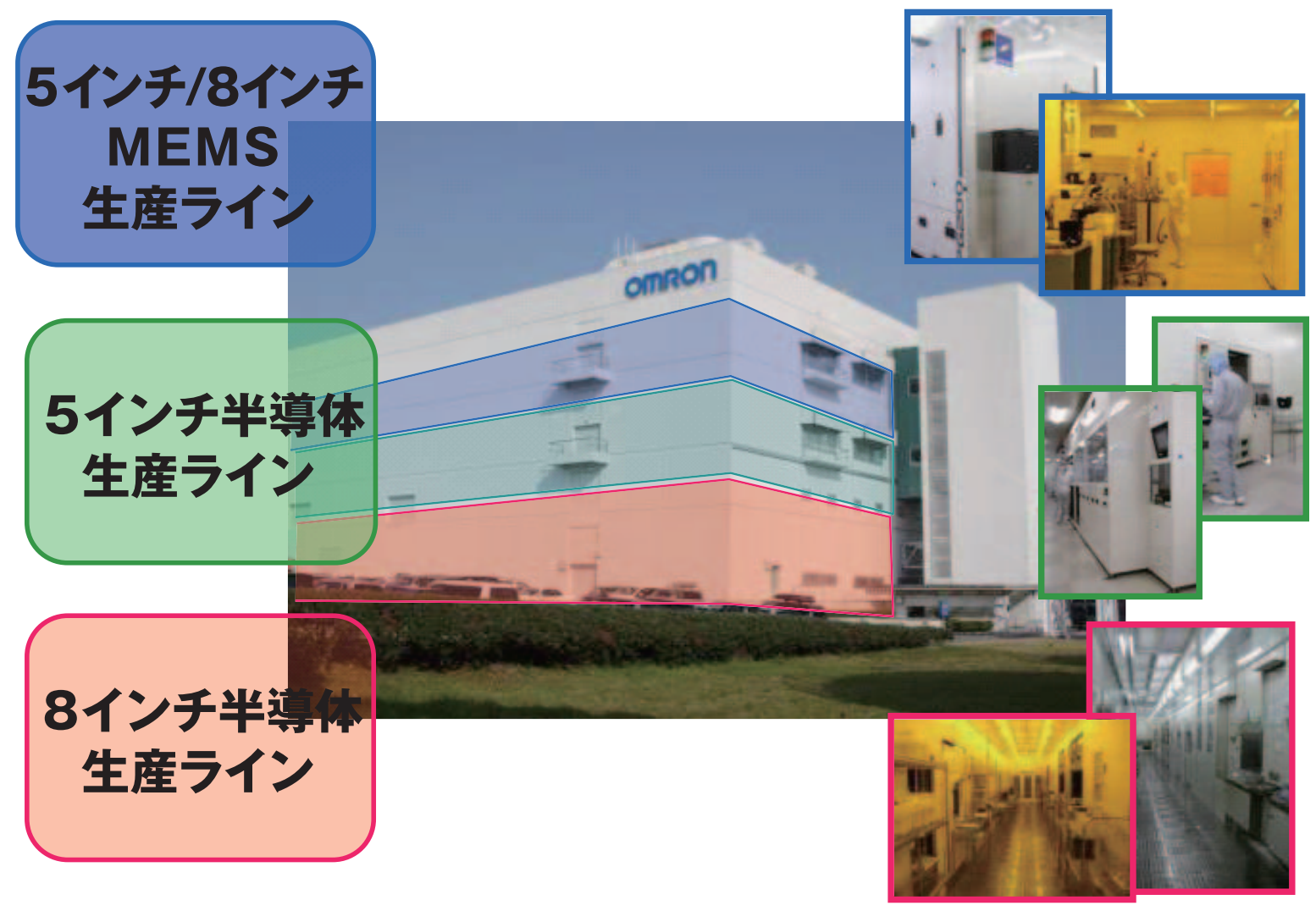

オムロンの MEMS 生産ライン
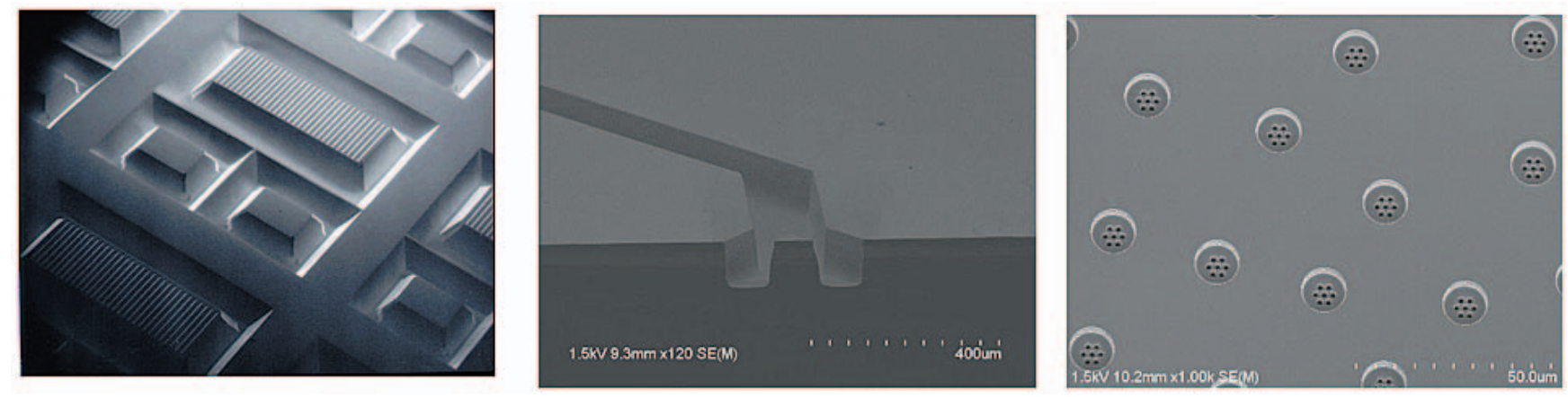

MEMS ファウンダリ加工例
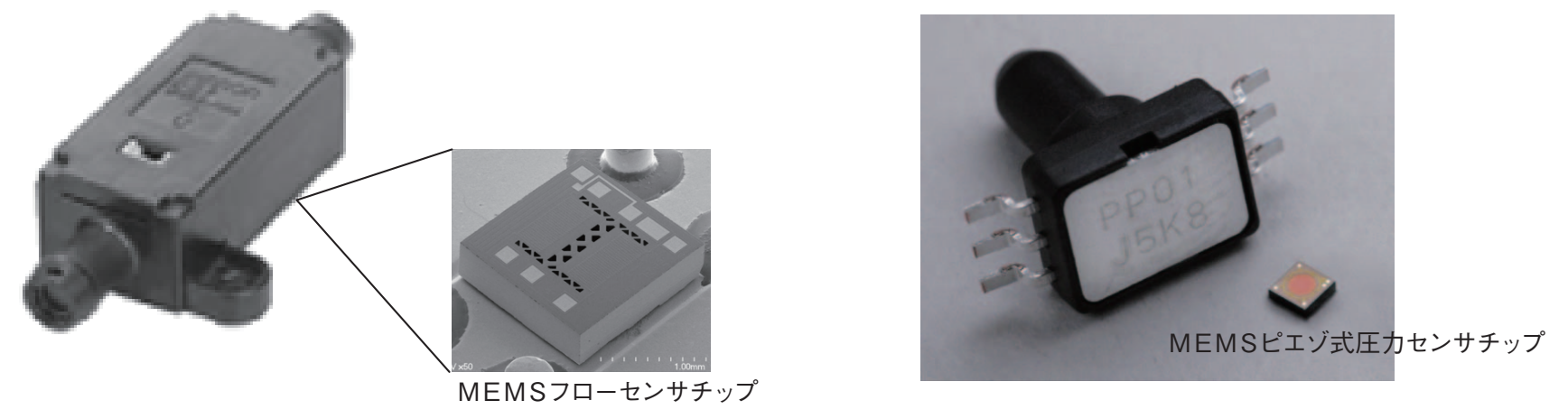

$$
\text { フローセンサ }
$$

ピエゾ式圧カセンサ 
本日は，オムロン株式会社野洲事業所 に伺って, MEMS 製品の商品化展開 を支えるファウンダリサービスについ て，お話を伺いました.

Q 最初に, 御社のマイクロデバイス 事業の概要を教えてください.

マイクロデバイス事業推進本部は, オムロンの中で唯一半導体事業を担当 している部署になります。オムロンは コア技術であるセンシング\&コント ロール技術をコアコンピタンスとし て，さまざまな事業を展開していま す。センシング\&コントロール技術に はいくつかの要素技術がありますが, われわれマイクロデバイス事業部では $\mathrm{MEMS}$ /半導体技術を中心として事業 展開しています。オムロンの MEMS 技術への取り組みは古く，1980 年代 後半には研究をスタートしています。 90 年代中ごろには, 最初の MEMS 商 品である血圧計用圧力センサを商用化 しました。 その後, フローセンサをは じめとしたさまざまな MEMS 商品を 世に送り出しています。

\section{Q 野洲事業所の沿革について教えて} ください.

野洲事業所はかなり広い敷地を保有 しています. 1970 年前後, 当時の日本 IBM 社がこの地で事業を展開されて おり，半導体から大型コンピュータま で一貫し開発・生産を行っていました。 IBM 社半導体事業がセイコーエプソ ン社に譲渡された後，2007 年 4 月に オムロンがセイコーエプソン社から 8 インチ製造ラインの譲渡をうけて，才 ムロンセミコンダクターズ（OSC）を 設立しました。 2008 年 7 月にはオム ロンが OSC を吸収合併し, 現在に至っ ています

Q ファウンダリサービスを始められ た経緯についてお聞かせください.

\section{MEMS商品化を支えるファウンダリサービス}

\section{オムロン株式会社 マイクロデバイス事業部}

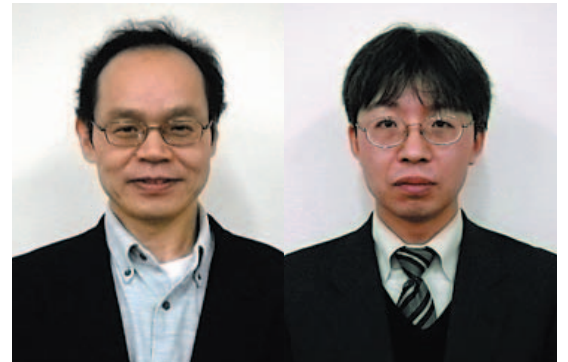

ロ絵グラビア参照

マイクロデバイス事業部 開発部 部長 伊藤 義武氏 (左)

商品企画課 主事

城島正男氏（右）

インタビュア/日本電信電話株式会社 水上 雅人

いわゆる一般的に認識されている ファウンダリは IC などの半導体事業 関連であることが多いです，半導体事 業関連のファウンダリは，今では基幹 産業となるくらいの巨大市場となって いますので，皆さんはよくご存知のこ とと思います。しかしながら，MEMS の場合には，半導体とは生い立ちが異 なるため，半導体事業関連で言われる ファウンダリという概念と MEMS の ファウンダリを一緒に考えるとおかし な議論になってしまうと考えていま す. 半導体事業とは, 設計, プロセス, テスト等の標準化がなされており，そ の結果水平分業が進んでいます。一方 でMEMS の場合は，まだ標準化がな されていない状況にあります。例えば 加速度センサを例にとってみても，設 計, プロセス, テスト, 実装・パッケー ジングのすべてにおいて各社各様の状 態です。そのため水平分業するのは難 しい状況にあります。半導体事業のよ うに 20 兆円規模の産業になるために は，ある程度水平分業されるようにな らないといけないと感じています。将 来的な水平分業を見据えて，これまで オムロンでは 8inchMEMS 製品のプロ セスに関しては，できるだけ標準化す るよう進めています。自社で培ってき た半導体技術をべースに自社製品で標 準化を指向したプロセスを立ち上げ, 実績を作ることがお客様のニーズに貢 献できるファウンダリサービスを提供
できると考えているからです.

MEMS を自社で製品化しようとす る企業にとっては, 商品ごとにプロセ ス装置が違うために，巨額の設備投資 が必要となる場合が多いです。すなわ ちアイデアはあっても事業展開するの が難しいことになります。また大学や 研究機関においても, いい技術, いい アイデアがあってもそれを試作しよう とした場合にさまざまなプロセス設備 が必要となります。大学, 研究機関で は多くのプロセス装置を揃えるのは難 しく，いいアイデアが具体化できない ということが危惧されます。さらに半 導体開発では，標準化されたプロセス をもとにした設計が可能なために，設 計〜量産を比較的容易に行えますが, MEMS 開発では, 設計と製造のフィー ドバックを何回も回さないと，高歩留 り，高品質のものはできないのが現状 です。そこで大学や研究機関を含め て, MEMS 産業を大きくすることに 貢献できればということで，オムロン のもっているこれまで蓄積してきた設 計・製造技術のノウハウを生かして, 一緒に物を作っていきたいというとこ ろが発端としてあります。

Q ファウンダリサービスの概要につ いて, どのような設備があって, どの ような部品を製作できるのかなどをご 紹介ください. 
オムロンはファウンダリ専業メーカ ではないために, 自社の MEMS/半導 体製品を製造するための設備を使用し たファウンダリを実施しています。

オムロンでは, 1990 年代半ばより 滋賀県の水口工場で MEMS 製品の量 産を始めており，ほぼ同時期よりファ ウンダリサービスも開始しています. 自社の MEMS 製品の製造設備が有効 活用されており，お客様には研究機関 が多い状態でした。研究機関が「何か 物にしてみたい」，「評価してみたい」 という場合に，お役に立てればという ことでファウンダリサービスをやって いた歴史があります。

水口工場の設備は現在では野洲事業 所に移転され, 場所を変えてファウン ダリサービスを継続しています。

野洲事業所では, 半導体製造ライン, 5 インチの MEMS 製造ラインと新設 の 8 インチの MEMS 製造ラインを保 有しています５インチ MEMS 製造 ラインでは圧力センサ等の製品を製造 しており，パターニングからウェッ ト・ドライエッチング装置, ウエハ接 合装置, ダイシング装置までの一通り の加工装置を揃えています．8インチ MEMS 製造ラインでの代表的な製品 としてはアコースティックセンサチッ プがあり，ダイヤフラム膜の形成に必 要なドライ・ウェットエッチング装 置, ウェハ裏面へのパターン形成用の 両面アライナをはじめとしたウエハの パターニングから DRIE などエッチン グ装置, ダイシング装置まで一通りの 加工装置は揃えています.
Q ファウンダリサービスが MEMS 商品化検討のサイクルを加速するもの と期待されますが, サービス展開にあ たり，技術的に難しい点はどのあたり でしょうか.

MEMS ファウンダリの場合は標準 化が進んでいないために，ある仕様を 提示すれば物ができるというところま では至っていない状況です.

また MEMSの製造にあたっては, ウェハプロセスが終わった段階では最 終的な製品の特性まで分からないケー スが多くあります。パッケージに組ん でみると特性が変化してしまうケース が多々あるのが現状です。 パッケージ そのものも MEMS の特性に影響する ので, 設計とプロセス, テスト, 実装・ パッケージング等のすべての工程を一 つのシームのごとく運営していかない とうまくいかないのが難しい点かと思 います。そのためには, プロセスを受 け持つ人も, 設計のノウハウと後工程 を分かっていないといけないわけで, 「加工はできますが, 後は知りません」 ということでは, いい製品はできない と考えています.

Q 日本のファウンダリ（オムロン株 式会社）の得意とする技術はどのよう なものでしょうか.

半導体に関しては，長年にわたる技 術が蓄積されており，量産化に関して 高い技術があると思っています。また 個々のプロセス技術に関しても，これ
までの商品開発を通じてノウハウが蓄 積されており, ファウンダリサービスを 展開するときの強みとなっています.

MEMS に関しては，15 年以上にわ たって量産経験を保有しています。ま た多様な MEMS 商品を世に送り出し ており，デザイン関連のノウハウも保 有しています。また薄膜形成技術にお きましてもノウハウが蓄積されている と思っています。

バリエーションに富んだ MEMS 開 発，量産で蓄積したわれわれのさまざ まなノウハウ，技術がファウンダリ サービスへ幅広く展開可能であると考 えています。

Q MEMS/NEMS ファウンダリを展 開するにあたり，精密工学が果たす役 割や期待するところがございました ら，お聞かせください.

MEMS 技術を使うことで，小型化， 低消費電力, 高信頼性等のさまざまな 価值を顧客に提供できます。MEMS 技術とは加工技術, 制御技術, 実装技 術, 評価技術等の集合体であり, ファ ウンダリサービスを展開していく上 で,これらの精密工学分野の技術が貢 献するところは大きいと思います.

本日はお忙しいところ，貴重なお話を 聞かせていただいて，有難うございま した. 